\title{
Mercury, hydroquinone and clobetasol propionate in skin lightening products in West Africa and Canada
}

Mètogbé Honoré Gbetoh ${ }^{1}$, Marc Amyot $^{1^{*}}$

${ }^{1}$ Département de sciences biologiques, Université de Montréal, Montréal, QC, Canada, H2V 2S9

*Corresponding author: Marc Amyot. Phone: 514-343-7496. Fax: 514-343-2293. E-mail: m.amyot@umontreal.ca.

This document is the unedited Author's version of a Submitted Work that was subsequently accepted for publication in Environmental Research, copyright (C) 2016 Elsevier Inc after peer review. To access the final edited and published work see http://www.sciencedirect.com/science/article/pii/S0013935116302651?via\%3Dihub 


\section{Highlights}

- 93 lightening soaps and 98 creams were purchased in West Africa and Canada.

- Mercury, hydroquinone and clobetasol propionate were measured.

- 68 to $84 \%$ of all creams exceeded regulatory guidelines.

- Levels reported on labels were often inaccurate. 


\begin{abstract}
Skin lightening products are types of cosmetics (creams, gels, lotions and soaps) applied voluntarily on skin. Several of these products contain a variety of active ingredients that are highly toxic. Among those toxic agents, the present study focuses on mercury, hydroquinone, and clobetasol propionate. Out of the 93 lightening soaps and 98 creams purchased in large city markets in sub-Saharan West Africa and in small ethnic shops in Canada, 68 to $84 \%$ of all creams and 7.5 to $65 \%$ of all soaps exceeded regulatory guidelines for at least one active ingredient when considering different regulations. Mercury was found in high concentrations mainly in soaps, while hydroquinone and clobetasol propionate concentrations exceeded US FDA standards in some creams for all countries included in our study. Concentrations of the three compounds declared on labels of soaps and creams usually did not correspond to concentrations actually measured, particularly for mercury and hydroquinone. Overall, our results indicate that most studied skin-lightening products are potentially toxic and that product labels are frequently inaccurate with respect to the presence of toxic agents.
\end{abstract}

Keywords: cream, soap, skin, whitening, toxic, mercury, hydroquinone, clobetasol propionate 


\section{Introduction}

Skin lightening products are types of cosmetics sold as creams, gels, lotions and soaps that are applied voluntarily on skin. In many African and Asian countries, and in many large cities worldwide where communities from these countries reside, the use of skin lightening products is becoming increasingly popular (Lewis et al., 2012, Uram et al., 2010, Mahe et al., 2007, Petit et al., 2006). Previous studies conducted in major cities of some West African countries have shown that a significant proportion (between 26 and 67\%) of adult females used these products daily to lighten their skin (Dadzie and Petit, 2009). Several of these products claim to contain a variety of active ingredients that are highly toxic (Bocca et al., 2014, Al-Saleh et al., 2012, Mahe et al., 2007). Among those toxic agents, the present study focuses on mercury, hydroquinone, and clobetasol propionate. We selected these three ingredients amongst others because they are amongst the most toxic and most used agents in lightening products, and they are often subject to regulations (Groupe Thématique 'Peau Noire' de la Société Française de Dermatologie, 2011, Dadzie and Petit, 2009, Del Giudice et al., 2003).

Inorganic mercury (e.g. mercurous chloride, ammoniated mercury, mercurous oxides or mercuric chloride) is the form of mercury commonly found in skin lightening products (Olumide et al., 2008, Palmer et al., 2000). It is a very toxic element that can inhibit melanin production by competing with copper in tyrosinase, resulting in the appearance of paler skin (Engler, 2005, Denton et al., 1952). Its cutaneous absorption is carried out either through the epidermis or through the sweat glands, the sebaceous glands or hair follicles, and significant dermal absorption can occur depending on different factors such as hydration of the stratum corneum and the frequency of application of these products on the skin. Urinary excretion is the major route of elimination (Chan, 2011, Copan et al., 2015, Sin and Tsang, 2003). Inorganic Hg concentrates mainly in the kidney, in particular in the tubular region where lesions have been observed after acute oral intake of $\mathrm{Hg}^{2+}$ salts (Al-Saleh et al., 2005). With repeated 
applications, the cumulative effect of prolonged low-dose exposure may lead to nephrotoxic effects, proteinuria and nephritis (Al-Saleh et al., 2005, Engler, 2005). The central nervous system can also be affected by inorganic $\mathrm{Hg}$ under certain conditions. In fact, although penetration of the blood-brain barrier by inorganic mercury is poor, prolonged exposure can result in central nervous system accumulation and neurotoxicity (Copan et al., 2015, Chan, 2011).

Hydroquinone is a major benzene metabolite widely used in skin lightening products. It is a well-known hepatotoxic and carcinogenic agent (Enguita and Leitao, 2013). In contact with skin, hydroquinone acts as an alternate substrate of tyrosinase. In the place of tyrosine, which should be transformed into melanin, hydroquinone metabolizes into quinones and free radicals. These radicals can then attack melanocyte membranes exerting a cytotoxic effect (Gillbro and Olsson, 2011).

Creams containing clobetasol propionate are drug products that are normally sold in several countries to treat various skin conditions. These products are unfortunately diverted from their normal use and used by women for skin whitening. They have anti-inflammatory, antipruritic, and vasoconstrictive properties and are known to reduce production of the arachidonic acid and of prostaglandin (Hammarstrom et al., 1977). The mechanism by which the topical steroids lighten the skin, in general, is unclear (Dadzie and Petit, 2009). However, it seems that these molecules have a strong affinity for the specific receptors for the keratinocytes and the melanocytes causing a depigmenting effect (Roguedas-Contios and Garcia-Le Gal, 2005). They may have many adverse effects on user health (Fanny et al., 2014, Sene et al., 2008, Mahe et al., 2007).

Several standards have been established for these toxic agents by international and national organizations. In the case of hydroquinone products, they are officially banned in Canada and the European Union (EU, 2009, Hc-sc.gc.ca, 2015) but are still allowed in the United States and several countries of West Africa at a concentration up to 1.5 to 2\% (US FDA, 2016, Ivory Coast, 2015). 
However, mercury is banned in lightening products sold in the European Union and of Ivory Coast but allowed in cosmetics sold in Canada and the United States in concentrations up to $1 \mu \mathrm{g} / \mathrm{g}$ (Hc-sc.gc.ca, 2016, US FDA, 2016). Finally, most regulations consider that the standard limit of clobetasol propionate in dermatological preparations is $0.05 \%$ (US FDA, w/w) when it is sold with prescription.

The production, distribution and sale of these products normally regulated in several countries is nevertheless carried by informal channels making difficult the compliance with recommended standards (Bocca et al., 2014, Glenn, 2008). Many of these products are readily available on streets, markets, and in non-pharmaceutical shops in West Africa and North American cities with West African communities where control of these products by local health authorities remains difficult (Hamann et al., 2014, Adepoju-Bello et al., 2012, Peregrino et al., 2011, Glenn, 2008, Voegborlo et al., 2008). Because these products are popular and can pose many problems on user's health, it is important to establish if these standard limits are respected in skin lightening products sold in countries around the world, especially in West Africa where there are several cases of adverse effects associated with topical application of these products such as nephropathy and exogenous ochronose (Levitt, 2007, US FDA, 2009).

In this study, we focused on two geographical regions where females use these products and we determined mercury, hydroquinone, and clobetasol propionate in a wide variety of skin lightening creams and soaps. Specifically, we collected products from various local markets in West Africa and in Montreal (Canada), a large North American city with an important West African population. In Africa, we focused on Benin, Ivory Coast, Mali and Senegal. Our main objective was to determine the concentrations of different active ingredients commonly found in skin lightening products in West Africa and Canada, and to compare them with regulatory guidelines. We further tested if concentrations 
of active ingredients stated on product labels are accurate and therefore correctly inform the consumers on the risk associated with the product.

\section{Materials and methods}

\subsection{Sampling of skin lightening personal care products}

A total of 191 skin-lightening creams and soaps (98 creams and 93 soaps) commonly used by women were purchased from the local markets of West Africa and Canada. In West Africa, we collected the products in the largest markets of the cities of Cotonou (Benin) in August 2013, and Bamako (Mali), Dakar (Senegal) and Abidjan (Ivory Coast) in August-September 2014. In Canada, we bought imported products in June 2013 in a dozen of small ethnic beauty shops located in the city of Montreal. Most of the products analysed were imported from different countries of Asia (Malaysia, Thailand and India), EU (France, Italy, UK and Germany), and of North America (USA, Dominican Republic), whereas some were locally imported from Africa (Democratic Republic of the Congo, Ivory Coast).

We analyzed mercury in all soaps and creams of all countries, namely in 6 soaps and 18 creams purchased in Benin, in 27 soaps and 25 creams purchased in Ivory Coast, in 20 soaps and 12 creams purchased in Mali, in 23 soaps and 25 creams purchased in Senegal and in 17 soaps and 18 creams purchased in Montreal, Canada (Figure 2a).

We measured hydroquinone in all creams of all countries. Similarly, we measured clobetasol propionate in all creams except in those containing hydroquinone exceeding $2 \%$ because we did not expect the simultaneous presence of hydroquinone and clobetasol propionate in the same cream at high concentrations. We did not measure hydroquinone or clobetasol propionate in soaps because these 
ingredients are not expected in lightening soaps (Groupe Thématique 'Peau Noire' de la Société Française de Dermatologie, 2011).

\subsection{Mercury analyses}

Cream and soap samples were analyzed using an automatic MERCURY SP-3D analyzer (Nippon Instruments, Osaka, Japan) in accordance with USEPA method 7473. After combustion at $700^{\circ} \mathrm{C}$, mercury was converted catalytically to elemental mercury. Following dual gold amalgamation, the quantity of mercury was measured by cold vapor atomic absorption at a wavelength of $253.7 \mathrm{~nm}$. Between 10 to $100 \mathrm{mg}$ of soap and cream samples were placed on a layer of an additive (mixture of sodium carbonate and calcium hydroxide; EMD Chemicals, NJ, USA) in a ceramic boat as suggested by the supplier. The sample was then covered with a layer of the same additive. A layer of aluminum oxide $\left(\mathrm{Al}_{2} \mathrm{O}_{3}\right.$; Acros Organics) was placed over the sodium carbonate-calcium hydroxide layer. The aluminum oxide layer was covered with another layer of the additive. The boat was then transferred manually into the ceramic thermal decomposition tube. After feeding the samples, all operations from the sample decomposition to the mercury detection were automatically carried out with SP-3D mercury analyzer system. Reference materials (Tort-2, $270 \pm 60$ ng/g; Dorm-4, $410 \pm 55$ ng/g; National Research Council of Canada, Ottawa, Canada) were analyzed every 10 samples to ensure reproducibility and to assess analytical quality. The analyses were accepted when measurements of certified reference materials were in the certified range. Mean concentrations of certified materials were $284 \pm 1(n=5)$ and $383 \pm 2(n=$ 9) for Tort-2 and Dorm-4, respectively. The instrument detection limit (IDL) is $0.01 \mathrm{ng} / \mathrm{g}$. 


\subsection{Hydroquinone analyses}

To extract hydroquinone, we accurately weighed $0.050 \mathrm{~g}$ of skin lightening cream and added $10 \mathrm{~mL}$ of ethanol. Samples were incubated in a water bath for $20 \mathrm{~min}$ at $50^{\circ} \mathrm{C}$, and let to cool down before analysis (Al-Saleh et al., 2012). We determined hydroquinone by a high-performance liquid chromatography (HPLC) method slightly modified from Al-Saleh et al. (2012) (HPLC with a UV-DAD detector, Agilent 1200, Santa Clara, US). Briefly, $1 \mathrm{~mL}$ of each sample was filtered through a $0.45 \mu \mathrm{m}$ syringe filter and $20 \mu \mathrm{L}$ were injected into the HPLC. Hydroquinone was separated on $5-\mu \mathrm{m}$ particle $4.6 \times 150 \mathrm{~mm}$, Zorbax eclipse XDB-C18 column. Isocratic system was used with a mobile phase (90:10 water: acetonitrile) prepared daily and degassed prior to use. Detection was done at a wavelength of $289 \mathrm{~nm}$.

Retention time was $2.7 \mathrm{~min}$ and total run time was $6 \mathrm{~min}$. A stock solution of $1 \mathrm{mg} \mathrm{mL}^{-1}$ hydroquinone was prepared in methanol. Working calibration curves were prepared by spiking $0.05 \mathrm{~g}$ of cream with different volumes of stock solution. Hydroquinone standard was purchased from Sigma-Aldrich $\geq 99 \%$ (Saint Louis, US). The analytical recoveries were $102 \%, 101 \%, 98 \%$ and $98 \%$ with RSDs of $1.5 \%$, $0.58 \%, 1.53 \%$ and $2 \%$, respectively for four spiked cream samples.

\subsection{Clobetasol propionate analyses}

Clobetasol propionate (CP) was analyzed according to Nam et al. (2011). Briefly, approximately 2 g of cream was mixed to attain a homogeneous mixture, and $1 \mathrm{~g}$ was accurately weighed into a $10 \mathrm{~mL}$ volumetric flask. It was then diluted with $10 \mathrm{~mL}$ acetonitrile, shaken vigorously and precipitated by centrifugation, filtered through a $0.45 \mu \mathrm{m}$ syringe filter, and transferred into a $1-\mathrm{mL}$ vial. Instrumental and analytical conditions were the same as described by Nam et al. (2011) using HPLC with UV-DAD detector (Agilent 1200, Santa Clara, US). Separation was carried out on ZORBAX1 Eclipse XDB-C18, a $5 \mathrm{~mm} \mathrm{C18}$ column (150 mm x $4.6 \mathrm{~mm}$, Agilent Technologies, USA), with a flow rate of $1 \mathrm{~mL} \mathrm{~min}^{-1}$, 
column temperature of $27^{\circ} \mathrm{C}$, injection volume of $10 \mu \mathrm{l}$, and a total running time of $25 \mathrm{~min}$. HPLC method for separation of standards and samples were modified from Nam et al. (2011) as follows. The elution was carried out using mobile phases A ( $0.1 \%$ phosphoric acid in water) and B (acetonitrile) at $240 \mathrm{~nm}$. UV scan mode, which ranged from 210 to 400, was used. Standards and samples were separated with solution B. The calibration curve was prepared for clobetasol propionate obtained from Sigma Aldrich $\geq 98 \%$ (FLUKA, US) by adding suitable amounts of standard stock solution to blank samples in triplicate. The analytical recoveries were $100 \%, 99 \%$ and $99 \%$ with RSDs of $1.5 \%, 2.1 \%$, and $1.5 \%$ respectively for tree spiked cream samples.

\subsection{Determination of impurities}

Mercury and hydroquinone are naturally occurring agents. They are banned in some countries but regulations do not directly consider natural impurities. It is important to assess if the concentrations that we measured resulted from acceptable impurities or voluntary addition by the manufacturer. We plotted all measured mercury and hydroquinone concentrations in decreasing order (Suppl. Info: Fig. S2.1 to S2.3.). We drew a line at the breaking point where levels started to depart rapidly from background concentrations, and considered that levels below this point constituted acceptable impurities (Table S2). Products with such acceptable impurities were considered as not contravening to the ban.

\subsection{Statistical analyses}

Statistical analyses were done with R 2.15.0. Differences between concentrations of active ingredients in products from West Africa and Canada were assessed using Kruskal-Wallis nonparametric tests followed by Tukey's multiple comparisons test (Scherrer, 1984). Log10 transformation was used to perform boxplot for mercury in soap and cream because of some extreme values. A statistical 
probability level of $\mathrm{p}<0.05$ was considered statistically significant for all comparisons. We also calculated the proportions of products (soaps or creams) that exceeded regulatory limits.

\section{Results}

\subsection{Concentrations of active ingredients in soaps and creams}

\subsubsection{Mercury concentrations in soaps and creams}

We analyzed mercury in 93 lightening soaps and 98 creams. Levels of mercury in soaps ranged from $5.45 \times 10^{-5}$ to $8370 \mu \mathrm{g} / \mathrm{g}$ with a mean of $349 \mu \mathrm{g} / \mathrm{g}$ (Figure 1a). Median mercury concentrations in soaps from Benin, Ivory Coast and Canada were higher than those from Senegal and Mali. Maximum soap mercury concentrations in one country in West Africa (Benin) were $~ 8000$-times higher than the US FDA limit. When considering mercury ban in lightening products with a threshold impurity limit of 0.6 $\mu \mathrm{g} / \mathrm{kg}$ (see section 2.5.), we observed that all soaps purchased in Benin and Canada exceeded guidelines. Overall, $65.6 \%(61 / 93)$ of all soaps analyzed from all countries exceed $0.6 \mu \mathrm{g} / \mathrm{kg}$. Kruskal-Wallis test on mercury concentration in soaps revealed significant differences among mercury concentrations in soaps by country (Table S1). According to subsequent Tukey HSD posthoc tests, mercury concentrations in soaps purchased from Benin were significantly greater than in those purchased in other countries.

In creams, levels of mercury ranged from $4.8 \times 10^{-5}$ to $0.914 \mu \mathrm{g} / \mathrm{g}$ and were all below the US FDA standard limit $(1 \mu \mathrm{g} / \mathrm{g})$. All mercury concentrations in creams from Benin and Canada exceeded the impurity threshold of $0.6 \mu \mathrm{g} / \mathrm{kg}$, with mercury concentrations in creams from Benin (between $1.80 \times 10^{-3}$ and $4.25 \times 10^{-2} \mu \mathrm{g} / \mathrm{g}$ ) higher than in those from Canada (between $6.37 \times 10^{-4}$ and $9.85 \times 10^{-3} \mu \mathrm{g} / \mathrm{g}$ ) except

for one cream purchased in Canada that had a high concentration of mercury $(0.914 \mu \mathrm{g} / \mathrm{g})$. Creams 
purchased in Ivory Coast, Mali and Senegal had mercury concentrations below $0.6 \mu \mathrm{g} / \mathrm{kg}$ except for two creams from Senegal (Figure 1b).

\subsubsection{Hydroquinone concentrations in creams}

Among the 98 skin-lightning creams, levels of hydroquinone in creams ranged from 0 to $6 \%(\mathrm{w} / \mathrm{w})$ with a mean of $1.2 \%(\mathrm{w} / \mathrm{w})$. Median in Mali was $\sim 2$-times higher than the US FDA limit of $2 \%(\mathrm{w} / \mathrm{w})$ (Figure 1c). Levels of hydroquinone in creams bought in Mali were significantly higher than creams bought in Ivory Coast, Senegal and Canada (Table S1, Tukey's post hoc test; $P<0.05$ ). In Benin and Mali, hydroquinone concentrations exceeded US FDA standards in over 44\% of creams (Figure 2b). When considering European Union legislation that bans hydroquinone in skin lightening creams, we observe that $38 \%(37 / 98)$ of all creams analyzed exceed $0.5 \%(\mathrm{w} / \mathrm{w})$ which was defined as the acceptable impurity threshold (Table 1; Table S2). 


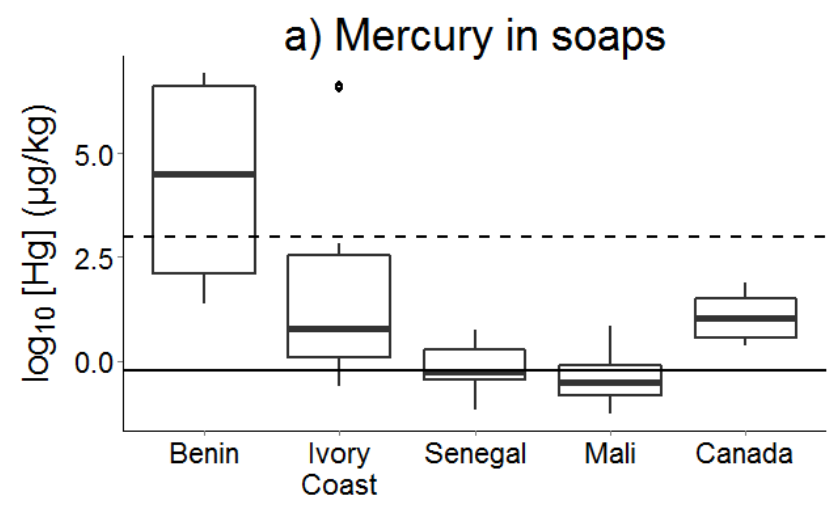

c) Hydroquinone in creams

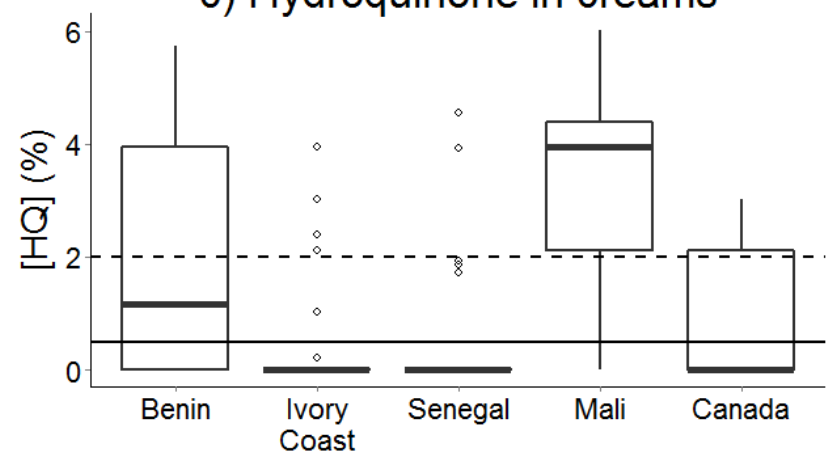

b) Mercury in creams

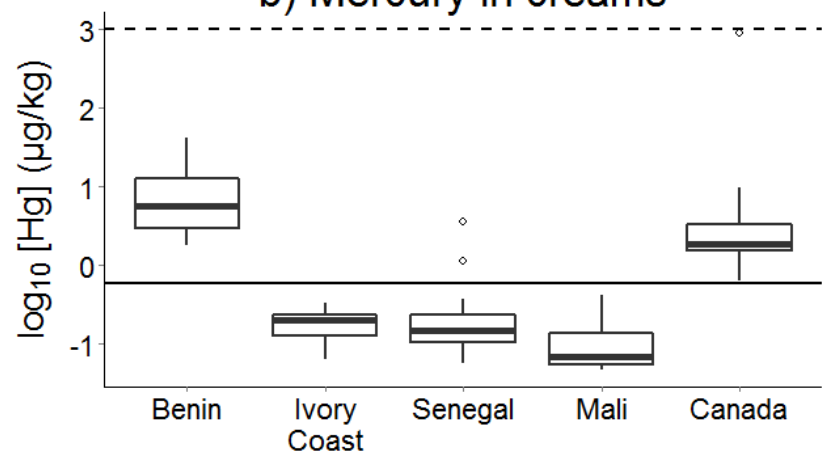

d) Clobetasol propionate in creams

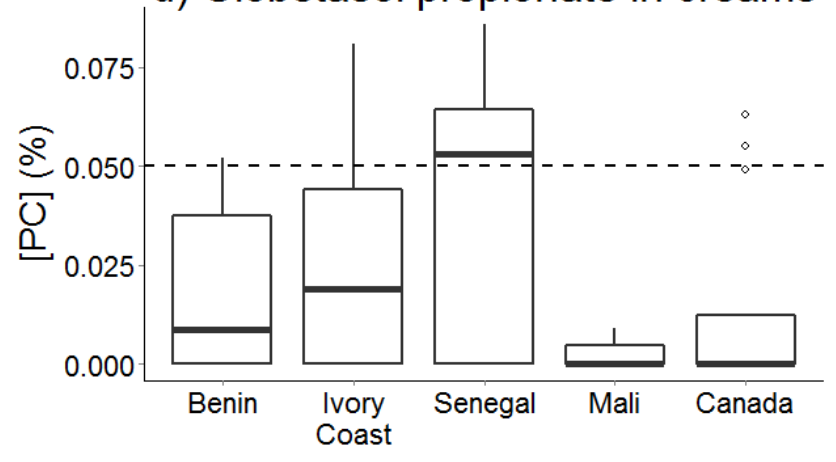

\section{Figure 1}

Boxplot showing (in $\mu \mathrm{g} \mathrm{Hg} / \mathrm{kg}$ ) minimum, median and maximum concentrations, and $25^{\text {th }}, 75^{\text {th }}$ percentiles of $\log _{10}(\mathrm{Hg})$ for mercury in soaps (a) and creams (b) in different countries in West Africa and Canada. Dotted line represents the US FDA threshold of $1 \mu \mathrm{g} \mathrm{Hg} / \mathrm{kg}$. Boxplot showing (in \%, w/w) minimum, median and maximum values and $25^{\text {th }}, 75^{\text {th }}$ percentiles of $\%(w / w)$ for hydroquinone in creams (c) in different countries in West Africa and Canada. Dotted line represents the US FDA threshold of $2 \%$ hydroquinone, $\mathrm{w} / \mathrm{w}$. Boxplot showing (in $\% \mathrm{w} / \mathrm{w}$ ) minimum, median and maximum values, and $25^{\text {th }}, 75^{\text {th }}$ percentiles of $\%(\mathrm{w} / \mathrm{w})$ for clobetasol propionate in creams (d) in different countries in West Africa and Canada. Dotted lines represent the US FDA threshold of $0.05 \%$ clobetasol propionate, w/w. Solid lines represent acceptable impurity thresholds (see section 2.5.).

\subsubsection{Clobetasol propionate concentrations in creams}

Creams containing clobetasol propionate at $0.05 \%(\mathrm{w} / \mathrm{w})$ are drug products and are banned from sale without medical prescription. In our study, when considering the bans of these products, clobetasol 
propionate was detected in $39 \%(38 / 98)$ of creams with a mean of $0.0265 \%(w / w)$. However, $20 \%$ (20/98) of creams exceeded US FDA standards limits of $0.05 \%$, $(\mathrm{w} / \mathrm{w})$ when we ignored their ban.

Levels of clobetasol propionate in creams bought in Senegal were significantly higher than in creams bought in Mali and Canada (Table S1, Tukey's post hoc test; $P<0.05$ ). The median in Senegal was $\sim 2$ times higher than in Benin (Figure 1d). Exceedance of US FDA limits (when creams are supposedly sold with medical prescription) was more common in creams purchased from West African countries than in those purchased in Canada, with $22.5 \%$ of creams exceeding $0.05 \%$; w/w limit in West Africa (5 to $50 \%$ depending on the country), compared to $11 \%$ in Canada (Figure 2b). 

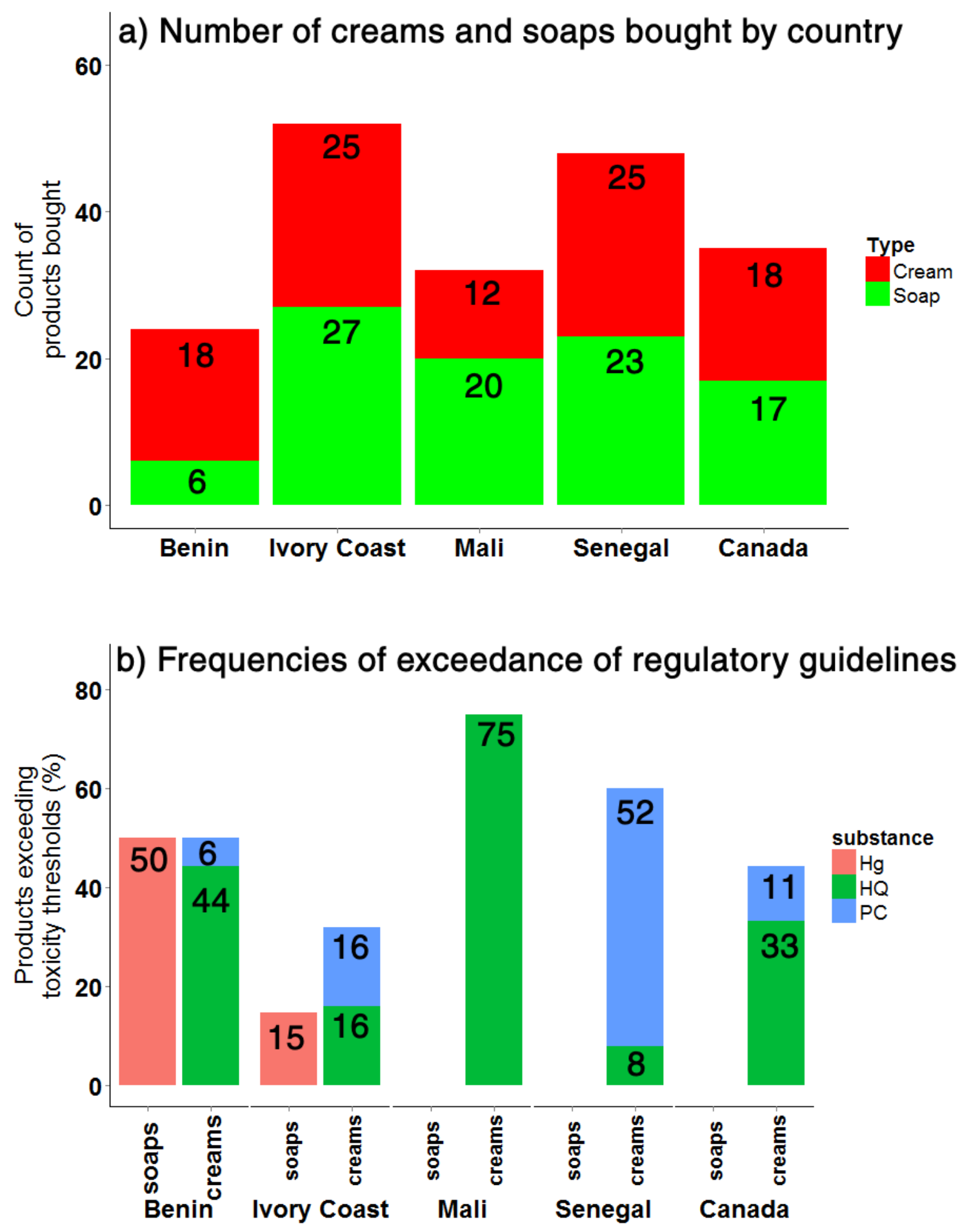

Figure 2

Histograms showing (a) the number of creams and soaps bought by country and (b) frequencies of exceeded regulatory guidelines by country, using US FDA standards not considering bans of PC. 


\subsection{Accuracy of labeling information}

In order to verify if concentrations of active ingredients listed on the labels are similar to those measured, we have selected soaps and creams for which manufacturers stated concentrations on the labels. For $\mathrm{Hg}, 2.6 \%(5 / 191)$ of products reported its presence on labels (between 1.2 to $2 \%$ mercury iodide, i.e. 5280 to $8800 \mu \mathrm{g} / \mathrm{g})$; for hydroquinone, $17 \%$ of creams $(17 / 98)$ listed concentrations of 1.2 to $2 \%$ on labels; for clobetasol propionate, $28 \%$ (27/98) of creams reported concentrations of $0.05 \%$ on the packaging.

For all three ingredients, we defined a gray area that represents a margin of $\pm 10 \%$ confidence around the declared value. When considering this gray area, we observe on Figure 3 that there was no relationship between concentrations mentioned on packaging and those measured by us in several products regardless of the country of purchase, indicating that labels inaccurately report concentrations of some potentially toxic ingredients (Figure 3a, 3b \& 3c).

Regarding mercury, 5 soaps purchased from Ivory Coast and Canada report presence of this ingredient on theirs labels at concentrations between 1.2 to $2 \%$ mercury iodide. However, mercury concentrations that we measured in these products were below values indicated on the labels (figure 3a). Moreover, we surprisingly measured high mercury concentrations (ranging from 8370 to $3520 \mu \mathrm{g} / \mathrm{g}$ ) in 5 other soaps purchased from West Africa that did not indicate the presence of $\mathrm{Hg}$ on their packaging.

In the case of hydroquinone, several products stating concentration of $2 \%$ on their labels had concentrations up to $5.5 \%$. Among these products, $82 \%$ of products ( 9 products of 11 ) purchased from West Africa (Benin and Mali) had concentrations of hydroquinone that exceeded by 2 fold the concentrations shown on labels (Figure 3b). When considering the gray area, 50\% of products 
purchased from Canada had hydroquinone concentration similar to declared values, and 50\% had levels 1.5 to 2 times higher than stated on the labels (Figure 3b).

For clobetasol propionate, products labelled as containing $0.05 \%$ clobetasol propionate had concentrations of up to $0.08 \% .65 \%$ of products (15 products of 23 ) purchased from West Africa (Benin, Ivory Coast and Senegal) had levels exceeding those reported on labels. However, when considering the gray area, most of clobetasol propionate concentrations measured were around the declared value except products purchased from Senegal and one cream purchased from Canada (Figure 3c). 

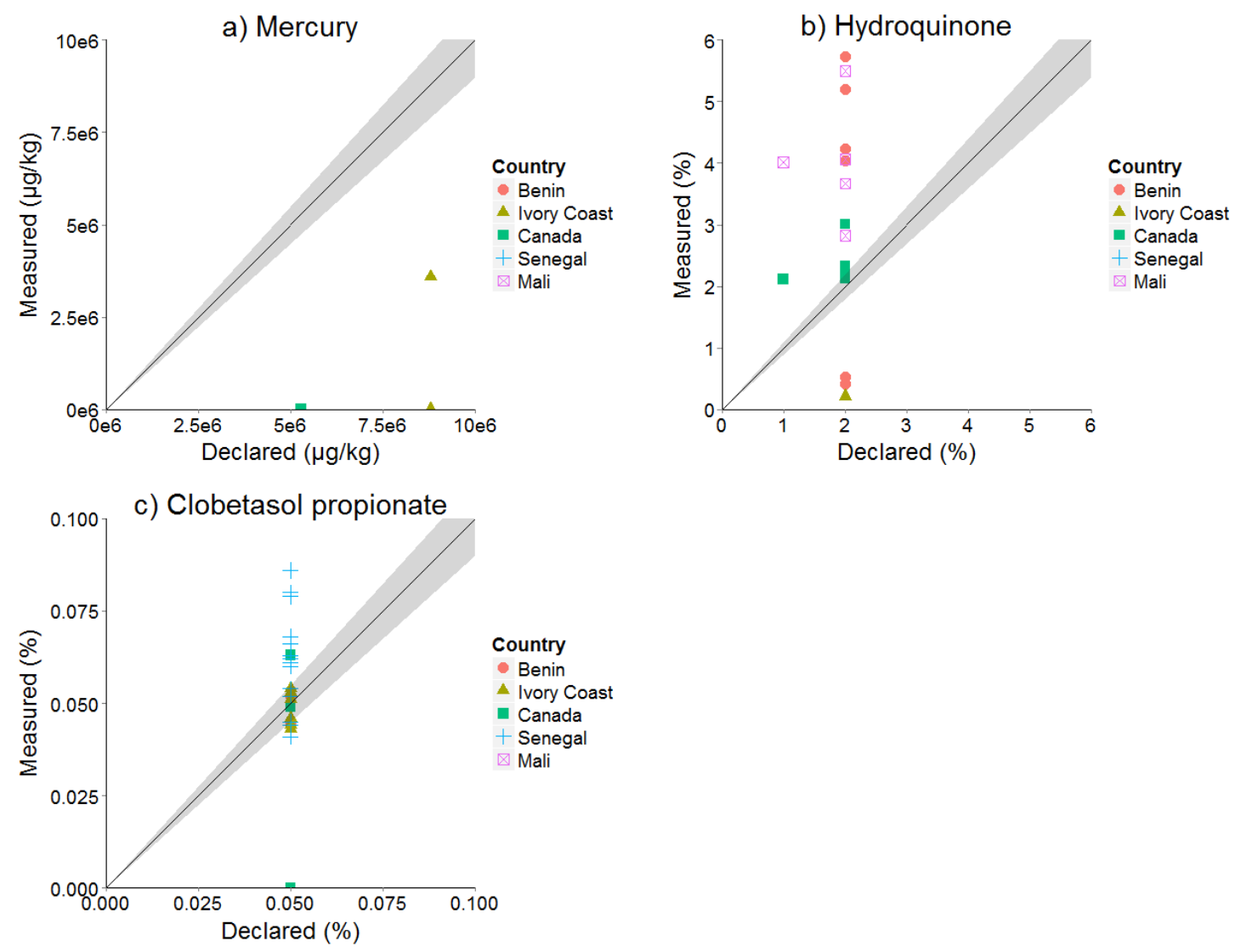

Figure 3.

Scatter plot showing correlations between mercury concentrations observed on packaging of the labels and concentrations of (a) mercury concentrations in creams and soaps, (b) hydroquinone in creams, (c) clobetasol propionate in creams. The gray area represents a margin of $\pm 10 \%$ confidence around the declared value. 


\section{Discussion}

\subsection{Are concentrations of toxic ingredients found in skin-lightening products of concern?}

In order to put our results in a broader context, we compared levels of toxic ingredients in skinlightening products to limits imposed by four regulatory agencies, namely the US FDA, Health Canada, the Regulation (EC) 1223/2009 and the Directive 76/768/EEC of the European Union and the Ministry of Commerce of the Ivory Coast (Table 1). In some cases, an ingredient was completely banned from sale without medical prescription; in these instances, all products containing the ingredient were considered as exceeding the limits; however, since $\mathrm{Hg}$ and hydroquinone are naturally occurring ingredients, we set a lower limit to distinguish between natural impurities and voluntary addition. A product was only considered as exceeding the limit in the case of banned substances if the ingredient exceeded the levels set for voluntary addition (Table S2).

Using this approach, we determined that 68 to $84 \%$ of all creams exceeded safety limits of at least one of the three toxic ingredients (Table 1). When ignoring the bans of some ingredients in products sold without prescription, 50 to $74 \%$ of creams exceeded the guidelines. We conclude that there is very important health risk associated with the sale of skin-lightening creams, since a large proportion of them exceeded national guidelines of multiple countries.

Whereas several studies have measured only one ingredient in lightening products (e.g. mercury), our approach of integrating simultaneously three types of toxic agents allowed for a more general appreciation of their health risks (see Table S5 in supplementary information for details about comparisons with guidelines by other authors).

The guidelines recommended by the US FDA to limit the presence of toxic agents in lightening products are used in many countries such as China and Mexico (Wang and Zhang, 2015, Peregrino et al., 2011). 
These standards are less stringent than those of the European Union that totally prohibit mercury, hydroquinone and clobetasol propionate in lightening products. They are also less stringent than those of some Western African countries such as the Ivory Coast that totally prohibit mercury and clobetasol propionate in lightening products. The stricter regulations of EU compared to US FDA led to $24 \%$ increase in the number of creams, and $58 \%$ of soaps exceeding standards.

This study shows that the problem of the presence of toxic active agents at high concentrations in lightening products arises in all the countries we studied. Other studies have also reported that many lightening products sold in certain countries such as Ivory Coast, Mali, Senegal, and other lightening products used in some Canadian immigrant communities, contain many toxic active agents (Hamann et al., 2014, Mistry et al., 2011, Uram et al., 2010, Ake et al., 2007, Mahe et al., 2007, Mahé et al., 2004, Del Giudice et al., 2003, Mahe et al., 2003, Mahé et al., 1993). Several of these studies have found very high concentrations of mercury in creams and soaps; notably, soaps purchased in Tanzania stand out for unknown reasons compared to those from other countries (Table 2). Other studies are based on concentrations mentioned on packaging of products to show that hydroquinone and clobetasol propionate were also in high concentrations in a wide variety of creams sold in West Africa, including Mali and Senegal (Mahe et al., 2007, Mahe et al., 2003, Mahé et al., 1993).

Although we found low concentrations of mercury in creams (below $1 \mu \mathrm{g} / \mathrm{g}$ ), our study clearly confirms the presence of mercury in soaps and of hydroquinone and clobetasol propionate in lightening creams at high concentrations. We identify hydroquinone and clobetasol propionate as key emerging toxic ingredients, although they are rarely analyzed when compared to $\mathrm{Hg}$. We suggest that these two ingredients be prioritized for future research in countries where they are now documented to be prevalent in products, i.e. all countries included in this study. 
We have never observed simultaneously high concentrations of three ingredients in the same product when considering US FDA limits (Table S4). These results are not consistent with a study conducted by Maneli et al. (2015) in South Africa that measured simultaneously mercury, hydroquinone and clobetasol propionate in two lightening products, although concentrations of hydroquinone and clobetasol propionate detected in these products were low compare to those of mercury. As all active agents can act on melanin formation and transfer, we do not expect to find more than one toxic agent in a given lightening product. However, this study was conducted in South Africa, while our products came from West Africa and Canada. It is possible that market pressures, constraints and controls are different in South Africa compared to West Africa.

\subsection{Are labels of skin-lightening product accurate?}

In order to verify the compliance of information mentioned on the labels of lightening products, we determined relationships between the concentrations of active ingredient stated on the labels of the products analyzed and the concentrations we measured. Overall, we found that most of manufacturers do not inform correctly consumers on the exact concentrations of active ingredients. These observations suggest an insufficient control by local authorities of products sold in large markets in West Africa and small ethnic beauty shops in Canada. We suggest the strengthening of regulation and of control on cosmetic products in order to limit exposure of the population to toxic ingredients and to more accurately inform consumers about risk. 


\section{Conclusion}

The results of our study confirm that mercury, hydroquinone and clobetasol propionate are still used in relatively high concentrations in skin lightening products. Soaps were more concentrated in mercury compared to creams which were much more concentrated in hydroquinone and clobetasol propionate. Several products which do not indicate the presence of mercury, hydroquinone and clobetasol propionate on their labels also had high concentrations of these ingredients. Because the levels of mercury, hydroquinone and clobetasol propionate detected in products often exceed regulatory guidelines, further study should be undertaken to better document the effect of these products on the health of consumers. With the recent advances in the relationships between microbiomes and human health, it would be particularly relevant to explore the effect of these personal care products on the skin microbiome, and how this can alter human health. The availability of contaminated products and their inaccurate labeling lead us to suggest that regulations should be more strictly enforced in countries where these products are sold.

\section{Acknowledgements}

This study was supported by an NSERC Discovery grant (\#217099) and the Canada Research Chair in Global Change Ecotoxicology (\# 950-230679) to MA. We thank Dominic Bélanger and Alexandre Poulain's lab for laboratory assistance and the anonymous reviewers for their comments on this work. MH.G. acknowledges financial support from Islamic Development Bank (IDB). 
Table 1: Frequencies of exceedance of regulatory guidelines for all ingredients tested according to different standards and considering the ban of non-prescription products. Definition of categories: considering bans: Exceedance frequency of all ingredients considering the ban of a toxic ingredient in non-prescription products; not considering bans: Exceedance frequency of all ingredients considering the thresholds used for products available with a medical prescription.

\begin{tabular}{|c|c|c|c|c|c|c|}
\hline & Categories & & & For all & For all soaps & For all products \\
\hline \multirow[t]{8}{*}{ US FDA limit } & \multirow[t]{4}{*}{ considering bans } & \multirow[t]{3}{*}{ For each ingredient } & $\mathrm{Hg}$ & $0(0 / 98)$ & $7.5(7 / 93)$ & \\
\hline & & & HQ & $29.6(29 / 98)$ & $0(0 / 93)$ & \\
\hline & & & $\mathrm{PC}$ & $38.7(38 / 98)$ & $0(0 / 93)$ & \\
\hline & & For all ingredient ${ }^{1}$ & $\mathrm{Hg}+\mathrm{HQ}+\mathrm{PC}$ & $68.3(67 / 98)$ & $7.5(7 / 93)$ & $38.7(74 / 191)$ \\
\hline & \multirow[t]{4}{*}{ not considering bans } & \multirow[t]{3}{*}{ For each ingredient } & $\mathrm{Hg}$ & $0(0 / 98)$ & $7.5(7 / 93)$ & \\
\hline & & & HQ & $29.6(29 / 98)$ & $0(0 / 93)$ & \\
\hline & & & PC & $20.4(20 / 98)$ & $0(0 / 93)$ & \\
\hline & & For all ingredient & $\mathrm{Hg}+\mathrm{HQ}+\mathrm{PC}$ & $50(49 / 98)$ & $7.5(7 / 93)$ & $29.3(56 / 191)$ \\
\hline \multirow[t]{8}{*}{ Health Canada limit } & \multirow[t]{4}{*}{ considering bans } & \multirow[t]{3}{*}{ For each ingredient } & $\mathrm{Hg}$ & $0(0 / 98)$ & $7.5(7 / 93)$ & \\
\hline & & & HQ & $37.7(38 / 98)$ & $0(0 / 93)$ & \\
\hline & & & $\mathrm{PC}$ & $38.7(38 / 98)$ & $0(0 / 93)$ & \\
\hline & & For all ingredient & $\mathrm{Hg}+\mathrm{HQ}+\mathrm{PC}$ & $74.4(73 / 98)$ & $7.5(7 / 93)$ & $41.8(80 / 191)$ \\
\hline & \multirow[t]{4}{*}{ not considering bans } & \multirow[t]{3}{*}{ For each ingredient } & $\mathrm{Hg}$ & $0(0 / 98)$ & $7.5(7 / 93)$ & \\
\hline & & & HQ & $38.7(38 / 98)$ & $0(0 / 93)$ & \\
\hline & & & $\mathrm{PC}$ & $20.4(20 / 98)$ & $0(0 / 93)$ & \\
\hline & & For all ingredient & $\mathrm{Hg}+\mathrm{HQ}+\mathrm{PC}$ & $58.1(57 / 98)$ & $7.5(7 / 93)$ & $33.5(64 / 191)$ \\
\hline \multirow[t]{8}{*}{ EU limit } & \multirow[t]{4}{*}{ considering bans } & \multirow[t]{3}{*}{ For each ingredient } & $\mathrm{Hg}$ & $38.7(38 / 98)$ & $65.6(61 / 93)$ & \\
\hline & & & HQ & $37.7(37 / 98)$ & $0(0 / 93)$ & \\
\hline & & & $\mathrm{PC}$ & $38.7(38 / 98)$ & $0(0 / 93)$ & \\
\hline & & For all ingredient & $\mathrm{Hg}+\mathrm{HQ}+\mathrm{PC}$ & $84.6(83 / 98)$ & $65.6(61 / 93)$ & $75.3(144 / 191)$ \\
\hline & \multirow[t]{4}{*}{ not considering bans } & \multirow[t]{3}{*}{ For each ingredient } & $\mathrm{Hg}$ & $38.7(38 / 98)$ & $65.6(61 / 93)$ & \\
\hline & & & HQ & $37.7(37 / 98)$ & $0(0 / 93)$ & \\
\hline & & & $\mathrm{PC}$ & $20.4(20 / 98)$ & $0(0 / 93)$ & \\
\hline & & For all ingredient & $\mathrm{Hg}+\mathrm{HQ}+\mathrm{PC}$ & $74.4(73 / 98)$ & $65.6(61 / 93)$ & $70.1(134 / 191)$ \\
\hline \multirow[t]{3}{*}{ Ivory Coast limit } & \multirow[t]{3}{*}{ considering bans } & \multirow[t]{3}{*}{ For each ingredient } & $\mathrm{Hg}$ & $38.7(38 / 98)$ & $65.6(61 / 93)$ & \\
\hline & & & HQ & $29.6(29 / 98)$ & $0(0 / 93)$ & \\
\hline & & & $\mathrm{PC}$ & $38.7(38 / 98)$ & $0(0 / 93)$ & \\
\hline
\end{tabular}




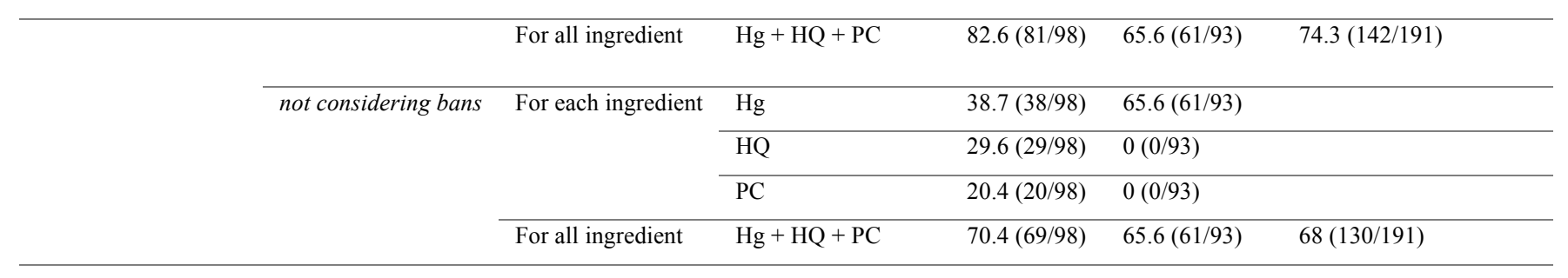

${ }^{1}$ See Table S3 for calculations of frequencies of exceeding regulatory guidelines for all ingredients tested according to different standards and considering the ban of non-prescription products. 
Table 2: Concentration of mercury, hydroquinone and clobetasol propionate in lightening products purchased from various countries.

\begin{tabular}{|c|c|c|c|c|c|}
\hline $\begin{array}{l}\text { Region/Country of } \\
\text { products purchase }\end{array}$ & {$[\mathrm{Hg}]$ soap $(\mu \mathrm{g} / \mathrm{g})$ (Range) } & {$[\mathrm{Hg}]$ cream $(\mu \mathrm{g} / \mathrm{g})$ (Range) } & $\begin{array}{l}{[\mathrm{HQ}] \mathrm{cream}} \\
(\%, \mathrm{w} / \mathrm{w}) \\
\text { (Range) }\end{array}$ & $\begin{array}{l}{[\mathrm{PC}] \text { cream }} \\
(\%, \mathrm{w} / \mathrm{w}) \\
\text { (Range) }\end{array}$ & References \\
\hline \multicolumn{6}{|l|}{ Africa } \\
\hline Benin & $2.36 \times 10^{-2}-8.37 \times 10^{3}$ & $1.80 \times 10^{-3}-6.86 \times 10^{-2}$ & $0-5.73$ & $0-0.052$ & Our study \\
\hline Ivory Coast & $2.42 \times 10^{-4}-4.48 \times 10^{3}$ & $6.30 \times 10^{-5}-3.39 \times 10^{-4}$ & $0-3.95$ & $0-00.081$ & Our study \\
\hline Mali & $5.45 \times 10^{-5}-6.65 \times 10^{-3}$ & $4.80 \times 10^{-5}-4.13 \times 10^{-4}$ & $0-6.02$ & $0-0.009$ & Our study \\
\hline Senegal & $2.98 \times 10^{-5}-5.39 \times 10^{-3}$ & $5.8 \times 10^{-5}-3.47 \times 10^{-2}$ & $0-4.56$ & $0-00.086$ & Our study \\
\hline Nigeria & & $9 \times 10^{-3}-2.07 \times 10^{-1}$ & & & $\begin{array}{l}\text { (Adepoju-Bello et al., } \\
\text { 2012) }\end{array}$ \\
\hline Senegal & & $<7 \times 10^{-3}$ & & & (Uram et al., 2010) \\
\hline Kenya & & $<7 \times 10^{-3}$ & & & (Uram et al., 2010) \\
\hline Kenya & $1.1 \times 10^{-1}-7.4 \times 10^{3}$ & & & & (Harada et al., 2001) \\
\hline Ghana & & $<7 \times 10^{-3}-7.9 \times 10^{-2}$ & & & $\begin{array}{l}\text { (Voegborlo et al., } \\
2008)\end{array}$ \\
\hline South Africa* & $1.9 \times 10^{3} \pm 10.00$ & $3 \times 10^{1} \pm 8.68-2.3 \times 10^{3} \pm 6.67$ & $<2$ & & (Maneli et al., 2015) \\
\hline Tanzania & $6.2 \times 10^{3}-7.4 \times 10^{3}$ & $<7$ & & & (Glahder et al., 1999) \\
\hline \multicolumn{6}{|l|}{ Middle East } \\
\hline Saudi Arabia & & $6.3710^{-1}-2.745$ & & & (Alqadami et al., 2013) \\
\hline Saudi Arabia & & $0-3.14 \times 10^{3}$ & & & (Al-Saleh et al., 2012) \\
\hline Saudi Arabia & & $1.02 \times 10^{-1}-7.75 \times 10^{-1}$ & & & (Al-Saleh et al., 2005) \\
\hline Saudi Arabia & & $0-5.65 \times 10^{3}$ & & & $\begin{array}{l}\text { (al-Saleh and al-Doush, } \\
\text { 1997) }\end{array}$ \\
\hline Saudi Arabia & & & $\begin{array}{l}0-4,186 \pm \\
0.195\end{array}$ & & (Al-Saleh et al., 2012) \\
\hline \multicolumn{6}{|l|}{ North America } \\
\hline Canada & $2.27 \times 10^{-3}-7.35 \times 10^{-2}$ & $6.37 \times 10^{-4}-0.914$ & $0-3.01$ & $0-0.063$ & Our study \\
\hline Mexico & & $<5 \times 10^{-3}-8.78 \times 10^{2} \pm 1.15 \times 10^{2}$ & & & (Peregrino et al., 2011) \\
\hline Mexico & & $<7 \times 10^{-3}-1.325 \times 10^{3}$ & & & (Uram et al., 2010) \\
\hline USA (Online) & & $1.044 \pm 121-9.603 \times 10^{3} \pm 1.14 \times 10^{2}$ & & & (Hamann et al., 2014) \\
\hline USA & & $\begin{array}{l}1.354 \times 10^{1} \pm 6.07 \times 10^{2}-3.291 \times \\
10^{1} \pm 2.127 \times 10^{3}\end{array}$ & & & (Hamann et al., 2014) \\
\hline USA & $4.77-4.38 \times 10^{2}$ & $3.37-4.160 \times 10^{1}$ & & & (McKelvey et al., 2011) \\
\hline
\end{tabular}

*South Africa data is not reported a range because mercury was detected in only one soap. 


\section{References}

ADEPOJU-BEllo, A., OGUNTIBEJU, O., ADEBISI, R., OKPALA, N. \& COKER, H. 2012. Evaluation of the concentration of toxic metals in cosmetic products in Nigeria. African Journal of Biotechnology, 11, 16360-16364.

AKE, M., OGA, S., BONY, N., AMIN, N. \& MALAN, A. 2007. Recherche et dosage du 17-propionate de clobétasol et du 17-, 21-dipropionate de bétaméthasone dans les crèmes et gels vendus sur les marchés publics d'Abidjan (Côte d'Ivoire). J Science Pharm Biol, 8, 25-33.

AL-SALEH, I. \& AL-DOUSH, I. 1997. Mercury content in skin-lightening creams and potential hazards to the health of Saudi Women. J Toxicol Environ Health, 51, 123-30.

AL-SALEH, I., EL-DOUSH, I., SHINWARI, N., AL-BARADEI, R., KHOGALI, F. \& AL-AMODI, M. 2005. Does low mercury containing skin-lightening cream (fair \& lovely) affect the kidney, liver, and brain of female mice? Cutan Ocul Toxicol, 24, 11-29.

AL-SALEH, I., ELKHATIB, R., AL-ROUQI, R., AL-ENAZI, S. \& SHINWARI, N. 2012. The dangers of skin-lightening creams. Toxicological \& Environmental Chemistry, 94, 195-219.

ALQADAMI, A. A., ABDAllA, M. A., ALOTHMAN, Z. A. \& OMER, K. 2013. Application of solid phase extraction on multiwalled carbon nanotubes of some heavy metal ions to analysis of skin whitening cosmetics using ICP-AES. Int J Environ Res Public Health, 10, 361-74.

BOCCA, B., PINO, A., ALIMONTI, A. \& FORTE, G. 2014. Toxic metals contained in cosmetics: a status report. Regul Toxicol Pharmacol, 68, 447-67.

CHAN, T. Y. 2011. Inorganic mercury poisoning associated with skin-lightening cosmetic products. Clin Toxicol (Phila), 49, 886-91.

COPAN, L., FOWLES, J., BARREAU, T. \& MCGEE, N. 2015. Mercury Toxicity and Contamination of Households from the Use of Skin Creams Adulterated with Mercurous Chloride (Calomel). International journal of environmental research and public health, 12, 10943-10954.

DADZIE, O. E. \& PETIT, A. 2009. Skin bleaching: highlighting the misuse of cutaneous depigmenting agents. Journal of the European Academy of Dermatology and Venereology, 23, 741-750.

DEL GIUDICE, P., RAYNAUD, E. \& MAHE, A. 2003. L'utilisation cosmétique de produits dépigmentants en Afrique. Bull Soc Pathol Exot, 96, 389-393.

DENTON, C. R., LERNER, A. B. \& FITZPATRICK, T. B. 1952. Inhibition of melanin formation by chemical agents. Journal of Investigative Dermatology, 18, 119-135.

DESMEDT, B., VAN HOECK, E., ROGIERS, V., COURSELlE, P., DE BEER, J. O., DE PAEPE, K. \& DECONINCK, E. 2014. Characterization of suspected illegal skin whitening cosmetics. $J$ Pharm Biomed Anal, 90, 85-91.

ENGLER, D. E. 2005. Mercury "bleaching" creams. J Am Acad Dermatol, 52, 1113-4.

ENGUITA, F. J. \& LEITAO, A. L. 2013. Hydroquinone: environmental pollution, toxicity, and microbial answers. Biomed Res Int, 2013, 542168.

EU 2009. Regulation (ec) no 1223/2009 of the European Parliament and of the Council of 30 november 2009 on cosmetic products. Official Journal of the European Union L, 342.

FANNY, A., COULIBALY, F., OUATTARA, A., SANGARE, Y., BERETE-COULIBALY, R., GBE, K. \& BONI, S. 2014. [Cataracts related to the extended application of dermocorticosteroids. A study of 8 cases in Abidjan]. J Fr Ophtalmol, 37, 388-92.

GILLBRO, J. M. \& OLSSON, M. J. 2011. The melanogenesis and mechanisms of skin-lightening agents--existing and new approaches. Int J Cosmet Sci, 33, 210-21.

GLAHDER, C. M., APPEL, P. W. U. \& ASMUND, G. 1999. Mercury in soap in Tanzania. National Environmental Research Institute. 
GLENN, E. N. 2008. Yearning for Lightness: Transnational Circuits in the Marketing and Consumption of Skin Lighteners. Gender \& Society, 22, 281-302.

GROUPE THÉMATIQUE 'PEAU NOIRE' DE LA SOCIÉTÉ FRANÇAISE DE DERMATOLOGIE 2011. [List of compounds used as cosmetics and reported as containing skin-lightening ingredients that are dangerous for health]. Ann Dermatol Venereol, 138, 443-6.

HAMANN, C. R., BOONCHAI, W., WEN, L., SAKANASHI, E. N., CHU, C. Y., HAMANN, K., HAMANN, C. P., SINNIAH, K. \& HAMANN, D. 2014. Spectrometric analysis of mercury content in 549 skin-lightening products: is mercury toxicity a hidden global health hazard? $\mathrm{J} \mathrm{Am}$ Acad Dermatol, 70, 281-7 e3.

HAMMARSTROM, S., HAMBERG, M., DUELL, E. A., STAWISKI, M. A., ANDERSON, T. F. \& VOORHEES, J. J. 1977. Glucocorticoid in inflammatory proliferative skin disease reduces arachidonic and hydroxyeicosatetraenoic acids. Science, 197, 994-996.

HARADA, M., NAKACHI, S., TASAKA, K., SAKASHITA, S., MUTA, K., YANAGIDA, K., DOI, R., KIZAKI, T. \& OHNO, H. 2001. Wide use of skin-lightening soap may cause mercury poisoning in Kenya. Science of the total environment, 269, 183-187.

HC-SC.GC.CA. 2015. Cosmetic Ingredient Hotlist - Consumer Product Safety [Online]. Available: http://www.hc-sc.gc.ca/cps-spc/cosmet-person/hot-list-critique/hotlist-liste-eng.php [Accessed 9 Apr. 2016].

HC-SC.GC.CA. 2016. Guidance on Heavy Metal Impurities in Cosmetics [Health Canada, 2012] [Online]. Available: http://www.hc-sc.gc.ca/cps-spc/pubs/indust/heavy metalsmetaux lourds/index-eng.php [Accessed 9 Apr. 2016].

IVORY COAST 2015. Decret n 2015-288 du 29 avril 2015 portant reglementation des produits cosmetiques et des produits d'hygiene corporelle.

LEVITT, J. 2007. The safety of hydroquinone: a dermatologist's response to the 2006 Federal Register. Journal of the American Academy of Dermatology, 57, 854-872.

LEWIS, K. M., GASKA, K., ROBKIN, N., MARTIN, A., ANDREWS, E. \& WILLIAMS, J. 2012. The Need for Interventions to Prevent Skin Bleaching A Look at Tanzania. Journal of Black Studies, 43, 787-805.

MAHÉ, A., BLANC, L., HALNA, J., KEITA, S., SANOGO, T. \& BOBIN, P. Enquête épidémiologique sur l'utilisation cosmétique de produits dépigmentants par les femmes de Bamako (Mali). Annales de dermatologie et de vénéréologie, 1993. Masson, 870-873.

MAHE, A., LY, F., AYMARD, G. \& DANGOU, J. M. 2003. Skin diseases associated with the cosmetic use of bleaching products in women from Dakar, Senegal. British journal of dermatology, 148, 493-500.

MAHÉ, A., LY, F. \& GOUNONGBÉ, A. 2004. La dépigmentation cosmétique à Dakar (Sénégal) : facteurs socio-économiques et motivations individuelles. Sciences sociales et santé, 22, 5-33.

MAHE, A., PERRET, J. L., LY, F., FALL, F., RAULT, J. P. \& DUMONT, A. 2007. The cosmetic use of skin-lightening products during pregnancy in Dakar, Senegal: a common and potentially hazardous practice. Trans $R$ Soc Trop Med Hyg, 101, 183-7.

MANELI, M. H., WIESNER, L., TINGUELY, C., DAVIDS, L. M., SPENGANE, Z., SMITH, P., VAN WYK, J. C., JARDINE, A. \& KHUMALO, N. P. 2015. Combinations of potent topical steroids, mercury and hydroquinone are common in internationally manufactured skin-lightening products: a spectroscopic study. Clin Exp Dermatol.

MCKELVEY, W., JEFFERY, N., CLARK, N., KASS, D. \& PARSONS, P. J. 2011. Population-based inorganic mercury biomonitoring and the identification of skin care products as a source of exposure in New York City. Environ Health Perspect, 119, 203-9. 
MISTRY, N., SHAPERO, J., KUNDU, R. V. \& SHAPERO, H. 2011. Toxic effects of skin-lightening products in Canadian immigrants. Journal of cutaneous medicine and surgery, 15, 254-258.

MURPHY, T., SLOTTON, D. G., IRVINE, K., SUKONTASON, K. \& GOLDMAN, C. R. 2009. Mercury contamination of skin whiteners in Cambodia. Human and Ecological Risk Assessment, 15, 1286-1303.

NAM, Y. S., KWON, I. K. \& LEE, K. B. 2011. Monitoring of clobetasol propionate and betamethasone dipropionate as undeclared steroids in cosmetic products manufactured in Korea. Forensic Sci Int, 210, 144-8.

ODUMOSU, P. \& EKWE, T. 2010. Identification and spectrophometric determination of hydroquinone levels in some cosmetic creams. African Journal of pharmacy and Pharmacology, 4, 231-234.

OlUMIDE, Y. M., AKINKUGBE, A. O., ALTRAIDE, D., MOHAMMED, T., AHAMEFUlE, N., AYANLOWO, S., ONYEKONWU, C. \& ESSEN, N. 2008. Complications of chronic use of skin lightening cosmetics. International Journal of Dermatology, 47, 344-353.

PALMER, R. B., GODWIN, D. A. \& MCKINNEY, P. E. 2000. Transdermal Kinetics of A Mercurous Chloride Beauty Cream: AnIn VitroHuman Skin Analysis. Journal of Toxicology: Clinical Toxicology, 38, 701-707.

PEREGRINO, C. P., MORENO, M. V., MIRANDA, S. V., RUBIO, A. D. \& LEAL, L. O. 2011. Mercury levels in locally manufactured Mexican skin-lightening creams. Int $J$ Environ Res Public Health, 8, 2516-23.

PETIT, A., COHEN-LUDMANN, C., CLEVENBERGH, P., BERGMANN, J. F. \& DUBERTRET, L. 2006. Skin lightening and its complications among African people living in Paris. $J$ Am Acad Dermatol, 55, 873-8.

ROGUEDAS-CONTIOS, A.-M. \& GARCIA-LE GAL, C. 2005. Dermocorticoïdes en dermatologie: modes d'action, indications, contre-indications, modalités d'application. Médecine thérapeutique, 11, 130-137.

SCHERRER, B. 1984. Biostatistique, Morin (Gaëtan).

SENE, D., HUONG-BOUtin, D. L., THIOllet, M., BARETE, S., CACOUB, P. \& PIETTE, J. C. 2008. [Symptomatic adrenal insufficiency secondary to the use of cutaneous topical steroids for skin-bleaching]. Rev Med Interne, 29, 1030-3.

SIN, K. \& TSANG, H. 2003. Large-scale mercury exposure due to a cream cosmetic: community-wide case series. Hong Kong Medical Journal, 9, 329-334.

URAM, E., BISCHOFER, B. P. \& HAGEMANN, S. 2010. Market analysis of some mercury-containing products and their mercury-free alternatives in selected regions, GRS.

US FDA. 2009. Supporting Information for Toxicological Evaluation by the National Toxicology Program, $21 \quad$ May $2009 \quad$ [Online]. Available: https://ntp.niehs.nih.gov/ntp/noms/support docs/hydroquinone may2009.pdf [Accessed Apr, 16th 2016].

US FDA. 2016. Prohibited \& Restricted Ingredients [Online]. Available: http://www.fda.gov/Cosmetics/GuidanceRegulation/LawsRegulations/ucm127406.htm [Accessed 9 Apr. 2016].

VOEGBORLO, R., VOEGBORLO, S., BUABENG-ACHEAMPONG, B. \& ZOGLI, E. 2008. Total mercury content of skin toning creams and the potential risk to the health of women in Ghana. Journal of Science and Technology (Ghana), 28, 88-96.

WANG, L. \& ZHANG, H. 2015. Mercury content in marketed cosmetics: analytical survey in Shijiazhuang, China. Cutan Ocul Toxicol, 34, 322-6. 


\section{Supplementary information}

Table S1: Kruskal-Wallis nonparametric and Tukey's multiple comparisons tests on concentrations of active ingredients in products from West Africa and Canada.

\begin{tabular}{|c|c|c|c|c|c|c|}
\hline \multirow[b]{2}{*}{ Analysis } & \multicolumn{3}{|c|}{ Kruskal Wallis test } & \multicolumn{3}{|c|}{ Tukey HSD Post hoc test } \\
\hline & Chi-squared & df & P-value & Class & Country & Mean \\
\hline \multirow{5}{*}{ [Hg]soap } & \multirow{5}{*}{51.171} & \multirow{5}{*}{4} & \multirow{5}{*}{$2.056 \mathrm{e}^{-10}$} & $\mathrm{a}$ & Benin & $2727000 \mu \mathrm{g} / \mathrm{Kg}$ \\
\hline & & & & $\mathrm{b}$ & Ivory Coast & $596300 \mu \mathrm{g} / \mathrm{Kg}$ \\
\hline & & & & $\mathrm{b}$ & Canada & $22.78 \mu \mathrm{g} / \mathrm{Kg}$ \\
\hline & & & & $\mathrm{b}$ & Senegal & $1.232 \mu \mathrm{g} / \mathrm{Kg}$ \\
\hline & & & & $\mathrm{b}$ & Mali & $0.884 \mu \mathrm{g} / \mathrm{Kg}$ \\
\hline \multirow{5}{*}{ Hg]cream } & \multirow{5}{*}{69.663} & \multirow{5}{*}{4} & \multirow{5}{*}{$2.674 \mathrm{e}^{-14}$} & $\mathrm{a}$ & Canada & $53.22 \mu \mathrm{g} / \mathrm{Kg}$ \\
\hline & & & & $\mathrm{a}$ & Benin & $10.71 \mu \mathrm{g} / \mathrm{Kg}$ \\
\hline & & & & $\mathrm{a}$ & Senegal & $0.336 \mu \mathrm{g} / \mathrm{Kg}$ \\
\hline & & & & $\mathrm{a}$ & Ivory Coast & $0.187 \mu \mathrm{g} / \mathrm{Kg}$ \\
\hline & & & & $\mathrm{a}$ & Mali & $0.129 \mu \mathrm{g} / \mathrm{Kg}$ \\
\hline \multirow{5}{*}[\mathrm{HQ}]{$\mathrm{cream}$} & \multirow{5}{*}{24.243} & \multirow{5}{*}{4} & \multirow{5}{*}{$7.141 \mathrm{e}^{-05}$} & $\mathrm{a}$ & Mali & $3.272 \%$ \\
\hline & & & & $a b$ & Benin & $2.024 \%$ \\
\hline & & & & $\mathrm{b}$ & Canada & $0.953 \%$ \\
\hline & & & & $\mathrm{b}$ & Senegal & $0.560 \%$ \\
\hline & & & & $\mathrm{b}$ & Ivory Coast & $0.508 \%$ \\
\hline \multirow{5}{*}{ [PC]cream } & \multirow{5}{*}{11.041} & \multirow{5}{*}{4} & \multirow{5}{*}{0.026} & $\mathrm{a}$ & Senegal & $0.043 \%$ \\
\hline & & & & $\mathrm{ab}$ & Ivory Coast & $0.023 \%$ \\
\hline & & & & $a b$ & Benin & $0.017 \%$ \\
\hline & & & & $\mathrm{b}$ & Canada & $0.013 \%$ \\
\hline & & & & $\mathrm{b}$ & Mali & $0.003 \%$ \\
\hline
\end{tabular}


Table S2: Acceptable impurities in the case of banned substances*

Ingredients Acceptable impurities

Hg in soaps $\quad 0.6 \mu \mathrm{g} / \mathrm{kg}$

Hg in creams $\quad 0.6 \mu \mathrm{g} / \mathrm{kg}$

HQ in creams $\quad 0.5 \%$

* These impurity limits were defined by us from our data, for legislations which completely ban these ingredients in cosmetics

Figure S2.1: Determination of acceptable impurities in the case that $\mathrm{Hg}$ is banned in creams
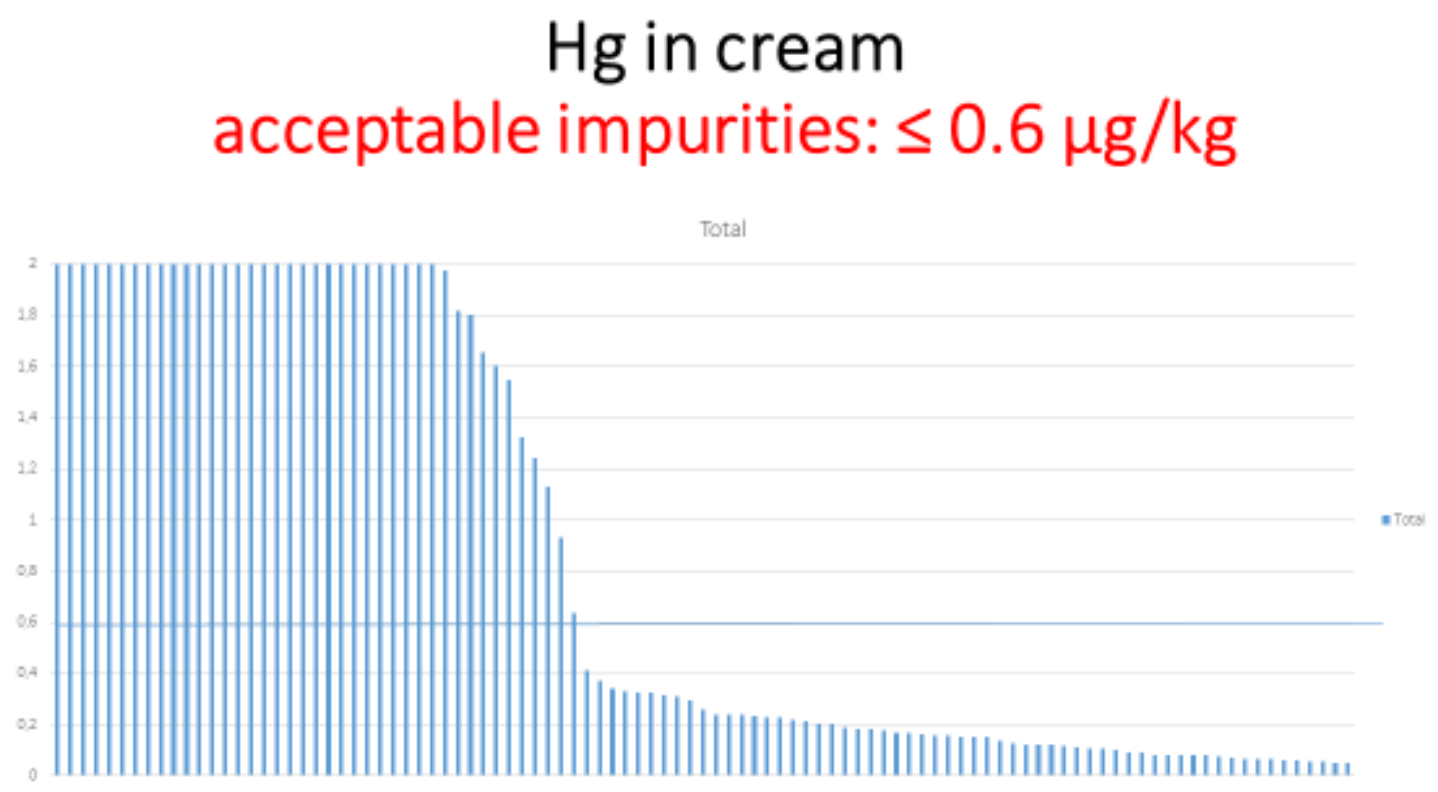
Figure S2.2: Determination of acceptable impurities in the case that $\mathrm{Hg}$ is banned in soaps

$$
\begin{gathered}
\text { Hg in soaps } \\
\text { acceptable impurities: } \leq 0.6 \mu \mathrm{g} / \mathrm{kg}
\end{gathered}
$$

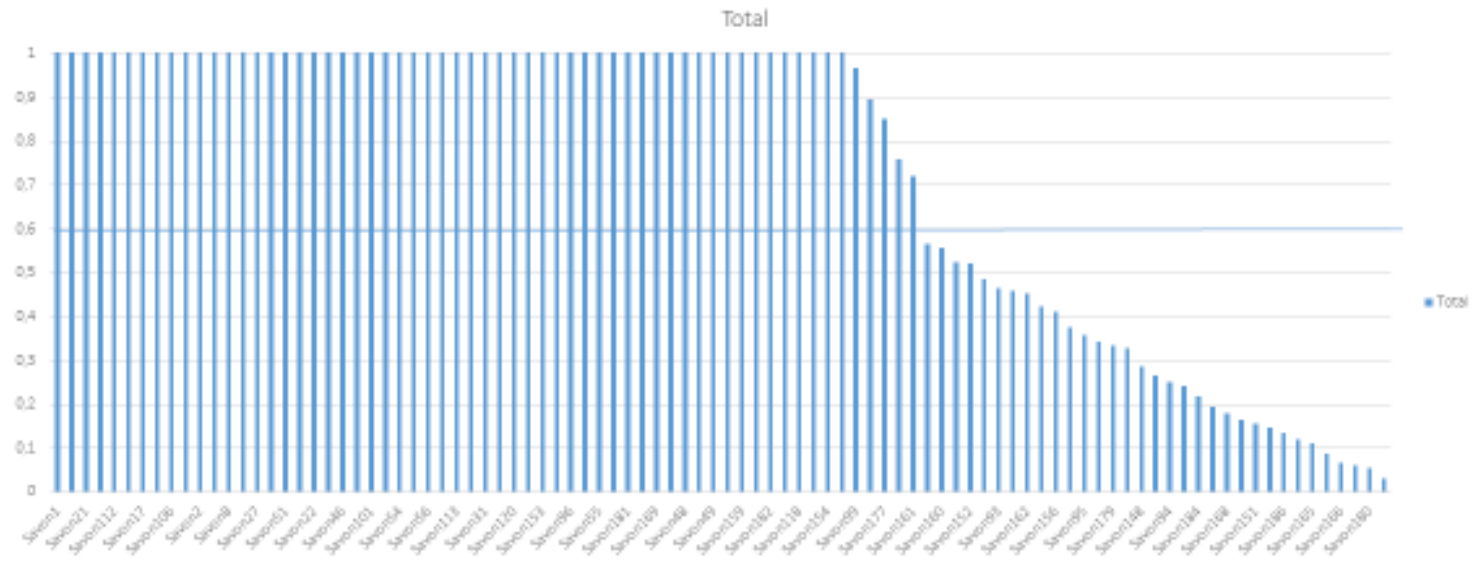


Figure S2.3: Determination of acceptable impurities in the case that HQ is banned in creams

\section{$\mathrm{HQ}$ in creams acceptable impurities: $\leq 0.5 \%$}

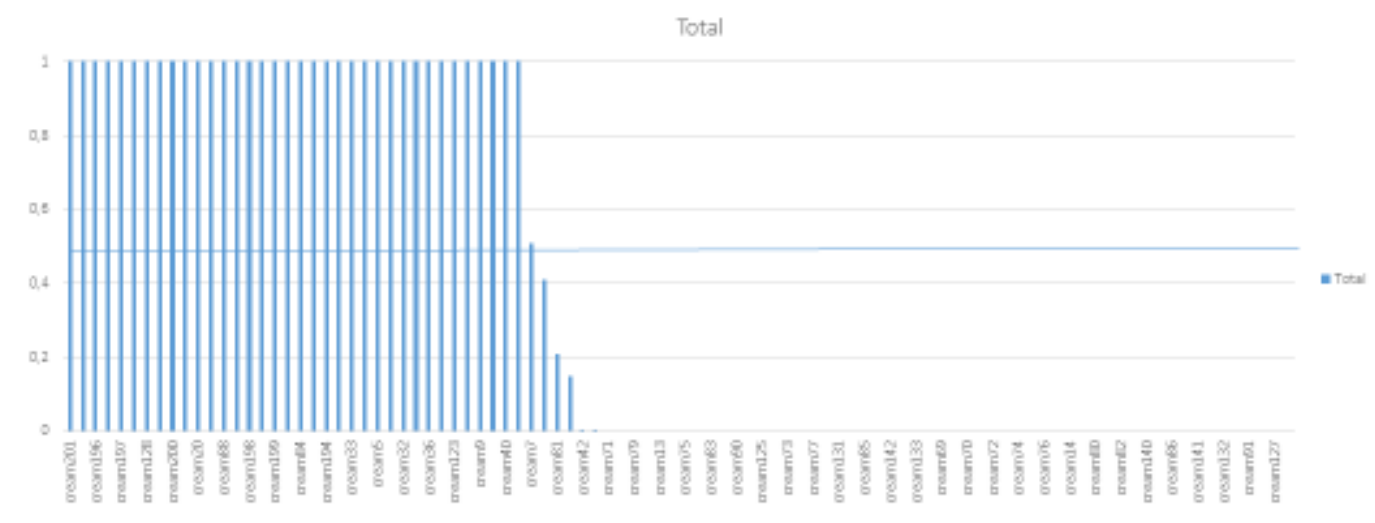

Table S3: Threshold values, for different regulations, when considering acceptable impurities.

\begin{tabular}{lllll}
\hline & Categories & PC & HQ & Hg \\
\hline US FDA limit & considering bans & $0 \%$ & $2 \%$ & $1 \mu \mathrm{g} / \mathrm{g}$ \\
\hline & not considering bans & $0.05 \%$ & $2 \%$ & $1 \mu \mathrm{g} / \mathrm{g}$ \\
\hline Heath Canada limit & considering bans & $0 \%$ & $0.5 \%$ & $1 \mu \mathrm{g} / \mathrm{g}$ \\
\hline & not considering bans & $0.05 \%$ & $0.5 \%$ & $1 \mu \mathrm{g} / \mathrm{g}$ \\
\hline EU limit & & & \\
\hline & considering bans & $0 \%$ & $0.5 \%$ & $0.6 \mu \mathrm{g} / \mathrm{kg}$ \\
\hline not considering bans & $0.05 \%$ & $0.5 \%$ & $0.6 \mu \mathrm{g} / \mathrm{kg}$ \\
\hline & & & $2 \%$ & $0.6 \mu \mathrm{g} / \mathrm{kg}$ \\
\hline
\end{tabular}

${ }^{1}$ Each product (cream or soap) that exceeds standard was counted once only. 
Table S4: Frequencies of exceedance of guidelines by more than one ingredient in a given product.

\begin{tabular}{|c|c|c|c|c|c|}
\hline & Categories & $\begin{array}{l}\text { \% of all same } \\
\text { creams excess } \\
\text { both } \mathrm{Hg}, \mathrm{HQ} \\
\text { and } \mathrm{PC} \\
\text { standards }\end{array}$ & $\begin{array}{l}\% \text { of all same } \\
\text { creams excess } \\
\text { both Hg and } \\
\text { HQ standards }\end{array}$ & $\begin{array}{l}\text { \% of all same } \\
\text { creams excess } \\
\text { both Hg and } \\
\text { PC standards }\end{array}$ & $\begin{array}{l}\text { \% of all same } \\
\text { creams excess } \\
\text { both HQ and } \\
\text { PC standards }\end{array}$ \\
\hline \multirow[t]{2}{*}{ US FDA limit } & considering bans & 0 & 0 & 0 & 0 \\
\hline & $\begin{array}{l}\text { not considering } \\
\text { bans }\end{array}$ & 0 & 0 & 0 & 0 \\
\hline \multirow{2}{*}{$\begin{array}{l}\text { Heath Canada } \\
\text { limit }\end{array}$} & considering bans & 0 & 0 & 0 & $3(3 / 98)$ \\
\hline & $\begin{array}{l}\text { not considering } \\
\text { bans }\end{array}$ & 0 & 0 & 0 & $1(1 / 98)$ \\
\hline \multirow[t]{2}{*}{ EU limit } & considering bans & 0 & $19.3(19 / 98)$ & $9.1(9 / 98)$ & $3(3 / 98)$ \\
\hline & $\begin{array}{l}\text { not considering } \\
\text { bans }\end{array}$ & 0 & $19.3(19 / 98)$ & $3(3 / 98)$ & $1(1 / 98)$ \\
\hline \multirow{2}{*}{$\begin{array}{l}\text { Ivory Coast } \\
\text { limit }\end{array}$} & considering bans & 0 & $15.3(15 / 98)$ & $9.1(9 / 98)$ & 0 \\
\hline & $\begin{array}{l}\text { not considering } \\
\text { bans }\end{array}$ & 0 & $15.3(15 / 98)$ & $3(3 / 98)$ & 0 \\
\hline
\end{tabular}


Table S5: Percentage of products (creams or soaps) exceeding regulatory guidelines for $\mathrm{Hg}$, of $\mathrm{HQ}$ or of PC published in other studies.

\begin{tabular}{|c|c|c|c|c|}
\hline & $\%$ in creams & $\%$ in soaps & $\%$ in (creams + soaps) & References \\
\hline \multirow[t]{12}{*}[\mathrm{Hg}]{$>1 \mathrm{ppm}$} & $0(0 / 146)$ & & & (Wang and Zhang, 2015) \\
\hline & $64.7(22 / 34)$ & & & (Alqadami et al., 2013) \\
\hline & $8.7(2 / 33)$ & & & (Al-Saleh et al., 2012) \\
\hline & $37.5(6 / 16)$ & & & (Peregrino et al., 2011) \\
\hline & $47.36(9 / 19)$ & & & (Murphy et al., 2009) \\
\hline & $100(21 / 21)$ & & & (Sin and Tsang, 2003) \\
\hline & $41.4(12 / 29)$ & & & (Maneli et al., 2015) \\
\hline & $45(17 / 38)$ & & & (al-Saleh and al-Doush, 1997) \\
\hline & $0(0 / 98)$ & $7.52(7 / 93)$ & $3.6(7 / 191)$ & Our study \\
\hline & $47(8 / 17)$ & $100(2 / 2)$ & $52.6(10 / 19)$ & (McKelvey et al., 2011) \\
\hline & \multicolumn{3}{|c|}{$57.14(8 / 14)$} & (Harada et al., 2001) \\
\hline & \multicolumn{3}{|c|}{$100(3 / 3)$} & (Glahder et al., 1999) \\
\hline$[\mathrm{Hg}]>10,000 \mathrm{ppm}$ & \multicolumn{3}{|l|}{$45 \%(247 / 549)$} & (Hamann et al., 2014) \\
\hline$[H Q]>2 \%$ & \multicolumn{3}{|l|}{$29.5(29 / 98)$} & Our study \\
\hline$[\mathrm{HQ}]>0,5 \%$ & \multicolumn{3}{|l|}{$37.7(37 / 98)$} & Our study \\
\hline$[\mathrm{HQ}]>\mathbf{0 , 5} \%$ & \multicolumn{3}{|l|}{$12(19 / 163)$} & (Desmedt et al., 2014) \\
\hline$[H Q]>1 \%$ & \multicolumn{3}{|l|}{$18.5(6 / 33)$} & (Al-Saleh et al., 2012) \\
\hline$[\mathrm{HQ}]>0,5 \%$ & \multicolumn{3}{|l|}{$100(10 / 10)$} & (Odumosu and Ekwe, 2010) \\
\hline$[H Q]>0,5 \%$ & \multicolumn{3}{|l|}{$37.9(11 / 29)$} & (Maneli et al., 2015) \\
\hline$[\mathrm{PC}]>0,05 \%$ & \multicolumn{3}{|l|}{$20.4(20 / 98)$} & Our study \\
\hline$[\mathrm{PC}]>0 \%$ & \multicolumn{3}{|l|}{$39.7(39 / 98)$} & Our study \\
\hline$[\mathrm{PC}]>0 \%$ & \multicolumn{3}{|l|}{$40(65 / 163)$} & (Desmedt et al., 2014) \\
\hline$[\mathrm{PC}]>0 \%$ & \multicolumn{3}{|l|}{$92.2(83 / 90)$} & (Ake et al., 2007) \\
\hline$[\mathrm{PC}]>0,05 \%$ & \multicolumn{3}{|l|}{$74.3(62 / 83)$} & (Ake et al., 2007) \\
\hline$[\mathrm{PC}]>0 \%$ & \multicolumn{3}{|l|}{$31(9 / 29)$} & (Maneli et al., 2015) \\
\hline \multicolumn{4}{|c|}{$\%$ of all products considered as illegal } & References \\
\hline \multicolumn{4}{|c|}{59} & (Desmedt et al., 2014) \\
\hline \multicolumn{4}{|c|}{75.9} & (Maneli et al., 2015) \\
\hline
\end{tabular}

